\section{The Practice of Entrepreneurial Competence Development among Students of the Maria Curie-Skłodowska University in Lublin}

\author{
Bartłomiej Twarowski \\ Maria Curie-Sktodowska University in Lublin, Poland \\ b.twarorski@umcs.pl
}

The Practice of Entrepreneurial Competence Development among Students of the Maria Curie-Skłodowska University in Lublin

\title{
Abstract
}

Purpose - the purpose of the article is to diagnose determinants of the effective development of entrepreneurial competence in members of the MCSU academic community and to develop a concept of a tool used for that purpose.

Design/Methodology/Approach - Polish and foreign literature was researched to find answers to the following questions:

1) What requirements are imposed on universities with regard to the development of entrepreneurial competence among students?

2) How should the effective education of adults be guaranteed?

3) What are the methodological bases for the realization of focus group interviews?

After that, focus research was carried out among 43 students from 11 faculties of the Maria Curie-Skłodowska University in Lublin to learn their opinions about:

- The way the essence of entrepreneurship and entrepreneurial attitudes and behaviour are perceived,

- conditions created by the University for entrepreneurial education and for the development of entrepreneurial attitudes and behaviours,

- factors that stimulate or block their entrepreneurship,

- preferred methods of development of entrepreneurial competences.

The obtained results of literature studies and focus interviews were used in order to develop the concept of an Entrepreneurship Academy or a complex program for the development of entrepreneurship in the academic community at the University.

Findings - entrepreneurial competences are among the ones of key importance for the successful functioning of people in the society as well as in their personal and professional lives. There is an urgent need to develop them and universities play an important role in satisfying it. To guarantee the best effectiveness of didactic processes focusing on the development of the knowledge of entrepreneurship, entrepreneurial attitudes and behaviour to members of the academic community, education curriculums should be developed considering the needs and preferences of the interested parties. Education methods based on learning in action and through experience should also be used.

Practical implications - the developed concept of the MCSU Entrepreneurship Academy is comprehensive and flexible. It is possible to be implemented in any school of higher education in full or in the form of its selected modules depending on the identified needs of the interested parties and financial resources available.

\section{Psynergía}

International Journal of Synergy and Research

Vol. 6, 2017 pp. $137-148$ 
IJSR

6
Original value - schools of higher education have varied curriculums related to entrepreneurship, however, the MCSU Entrepreneurship Academy is an end-to-end tool based on the holistic approach and involving the cooperation of entities representing all components of the entrepreneurship ecosystem in the socioeconomic vicinity.

Article type - research paper, case study.

Keywords - academic entrepreneurship, entrepreneurial competencies, entrepreneurship learning.

\section{Premises justifying the need for education relating to entrepreneurship in schools of higher education}

The "Sense of initiative and entrepreneurship" are considered key competencies in the lifelong learning process (Recommendation of the European Parliament and of the Council 2006/962/WE of 18 December 2006 on key competences for lifelong learning (OJ UE L 394 of 30.12.2006), pp. 10-18). Key competencies are indispensable to be an active citizen, for the purpose of social integration and employment, as well as selfrealization and personal development. The sense of initiative and entrepreneurship is defined as the ability to effectively implement ideas and consists of the creativity, readiness to take rational risks and the ability to plan ventures and realize them. The sense of initiative and entrepreneurship supports one in the private and professional life (Recommendation...).

Thanks to the international research carried out among 1,870 entrepreneurs and 60 research workers from 30 countries, Izquierdo and Deschoolmeester identified components of the competence in the entrepreneurship area that students should attain in the course of their higher education irrespectively of the direction of studies. They include (Izquierdo, Deschoolmeester, 2010, pp. 194-208):

- team building,

- innovative thinking,

- communication,

- evaluation of business opportunities,

- decision-making,

- problem identification and solving,

- recognition of business opportunities,

- negotiation skills.

It is possible to distinguish two key elements of the entrepreneurship education. The first one is the individual entrepreneurship referring to one's personal potential and manifesting, for example, as creativity or the ability to: communicate, present oneself, influence others, work in a group, cope with stress or make decisions in risky conditions. The second component consists of the business entrepreneurship covering knowledge and skills necessary to take up commercial and social ventures (see: Gawel, 2014, pp. 06-307).

According to the Report prepared by the Organization for Economic Cooperation and Development (OECD) and the European Commission (EC) titled "Supporting entrepreneurship and innovation in institutions of higher education in Poland", the majority of Polish schools of higher education more and more frequently offer a wide range of innovative forms of education. Didactic methods become more and more 
interactive but frequently remain rather traditional and usually consist of the lecturebased teaching. All institutions of higher education that took part in the research indicated that lectures were a commonly used form of teaching while work-based methods (e.g. solving true problems, learning through practice) were used much less frequently. Therefore, the teaching concentrating on knowledge transfer rather than the stimulation and development of desirable ways of thinking still prevails (Wspieranie przedsiębiorczości i innowacji $w$ instytucjach szkolnictwa wyższego $w$ Polsce; OECD and EC report of 2017). In the light of this fact, OECD and the EC formulated recommendations whose application should help Polish schools of higher education to attain the status of entrepreneurial institutions of higher education. These recommendations include (Wspieranie...):

- in each higher education institution, the establishment of a representative of the authorities responsible for the "third mission" of the school, including the innovations, entrepreneurship, and for building relations with the socioeconomic environment,

- implementation of the entrepreneurial component in the operation of advisory committees on the level of schools and faculties,

- encouraging and supporting the participation of the academic staff in international conferences on entrepreneurship,

- the application of more active methods of development of entrepreneurial competences,

- increasing the level of interdisciplinary aspects in the teaching of entrepreneurship,

- development of wider support programs for students working on high-potential projects.

\section{Methodological requirements for the entrepreneurship education process for adults}

Education of adults is of interest to researchers representing various branches of science. Many theories were formulated to explain why and how people learn. Scientists perceive the learning process as a set of activities leading to brain transformation, troubleshooting process, gaining of experience influencing human behaviour, the process of skill acquisition and the formulation and exchange of views (Tomaszewski, 1995).

The literature on the education of adults most frequently mentions the division into three groups of theories of learning (Horyń, Maciejewski, 2007):

- behavioural, referring to behaviour (behavioural theory),

- cognitive, integrating new knowledge with existing one (cognitive theory),

- social learning, assuming the existence of dependency between learning and the forecasted effectiveness of actions (social learning theory).

Adult learning is treated as a continuous and, at the same time, complex process. It occurs not only during didactic classes but also in the course of contacts with other people or during ordinary, daily life activities. Researchers representing the behavioural approach perceive the learning of adults as a process leading to changes in their behaviour as a result of the acquired information, observations made or experience gained (Bandura, 1977). New behaviour is acquired thanks to two mechanisms: learning through consequences and modelling (Bandura, 1977).
The Practice of Entrepreneurial Competence Development among Students of the Maria Curie-Skłodowska University in Lublin 
IJSR

6
Learning through consequences involves the choice of the behaviour whose consequences are likely to be desirable or not taking actions that resulted in undesirable consequences in the past. Therefore, knowledge of the consequences of actions is necessary to modify human behaviour. The modelling takes place through the observation of actions taken by other people and consequences they bring about. Prerequisites of the acquisition of new behaviour by a person include the observation of the behaviour of a model entity and knowledge of the consequences such behaviour brings about. One also has to remember such behaviour and try it out in one's own activity. Only behaviour with which one expects to attain desirable results is adopted (Wood, Bandura, 1989, pp. 361-384).

The two mechanisms described above are not automatic. Their activation requires awareness and concentration. Therefore, the learning process is regulated in a cognitive manner. One learns through action and experience while subjecting the consequences to analysis and interpretation. On that basis, decisions are made regarding ways to act to be used in the future. The confirmation of that thesis is contained in the Experiential Learning Model developed by D.A. Kolb et al. inspired by the works by K. Lewin (Kolb et al., 2011, pp. 227-247).

According to Kolb, an adult person learns by gaining experience and analysing it. The learning process consists of the following stages (Kolb, 2015, pp. 31-64):

1. Concrete experience;

2. Observation - analysis - reflection;

3. Abstract generalizing rules;

4. Application, action, verification.

Concrete experience is knowledge available, skills and also emotions whose compilation one attains through the observation and personal commitment to various situations. Experience allows for the rational observation of the surrounding reality, the analysis of observed dependencies and reflection. In turn, reflection makes it possible to create abstract generalizing rules in order to describe, evaluate and classify not just a single event but rather all events similar to it. Knowledge generated in this manner finds its application, becomes the basis for action during which its practical verification takes place. This process leads one to gaining new experience, which begins a new learning cycle (Kolb, 2015, pp. 31-64). The cycle is a continuous process that can begin at any stage. However, two issues are material. The first one is to select the stage at which the realization of the cycle begins. In this case, one has to consider preferences of participants in the learning process and the type of desirable competence to be developed by them. Secondly, it is important that all the stages mentioned have to be taken into account in the didactic process irrespectively of the stage at which it will begin. Kolb's model involves the treatment and understanding of learning as the collection of experience leading to changes in behaviour (Kolb, Kolb, 2005, pp. 2-3).

Learning is a process of continuous modification of previous experience by new experience. New ideas are not recorded as characters on a "pure white sheet of the mind" of the learner but rather interact with the ideas already acquired. Knowledge is gained thanks to the possibility to experience and live through various situations and also thanks to the exchange of experience. Adults are very unwilling to gain theoretical knowledge. They perceive the learning process as a challenge and find it easier to learn if they have 
a concrete goal. They approach learning as a troubleshooting process; this is why they prefer learning by gaining experience and reflecting upon it later. The effectiveness of the learning process in adults depends on their awareness of the purposefulness of that process; this is why competencies they are supposed to acquire in the learning process should be a direct value for them. It is also important for new knowledge to refer to areas already known to them and to concepts and ideas existing in their minds. Adults learn more effectively if their preferred learning style is taken into account in the didactic process, when they feel safe, can see advantages of knowledge gained and if they feel they can influence the learning process (Galbraith, 1998, pp. 3-19).

Entrepreneurship education has to meet a few conditions from the methodological perspective. It should be based on the solving of real problems (Tan, $\mathrm{Ng}, 2006$, pp. 416-428). It is vital for its form to be as adapted as possible to the needs of the interested parties. It is also important to apply the holistic approach when developing the education concept. It means that the entrepreneurship education should include both an individual and a business component. When developing the entrepreneurship education project, one should focus on a human being as a whole offering new knowledge, new ways of thinking, new abilities or behaviour to an individual (Heinonen, Poikkijoki, 2006, pp. 80-94). It is also indicated that the entrepreneurship education should comply with the learning by doing principle and commit trained individuals to the education process (Tan, Ng, 2006, pp. 416-428; Balan, Metcalfe, 2012, pp. 368-384).

\section{Diagnosis of needs of MCSU students in the entrepreneurship education process}

Quantitative research carried out at the Maria Curie-Skłodowska University in Lublin in 2014-2016 proved that entrepreneurship needs to be stimulated in the academic community of the University (Twarowski, 2016, pp. 125-134). Universities are perceived as organizations obliged to create entrepreneurial attitudes among students and to guarantee authentic support in the seamless transition from the academic activity to professional one (De Vos et al., 2009, pp. 1-28). To develop an entrepreneurship teaching program optimally adapted to the needs and preferences of the interested parties, a decision was made to conduct in-depth studies with the use of focused group interviews.

The method was developed during WW2 by two sociologists: P.F. Lazarsfeld and R.K. Merton. The method has a few names used in the literature devoted to the research methodology. The Focused Group Interview highlights the activity of a moderator who leads the interview with a few participants at the same time by asking questions. The term "focus group" indicates that participants in the research are focused on a specific topic while the term "group discussion" stresses the activity of participants interacting with one another and exchanging opinions (Rabiee, 2004, pp. 655-660). It is assumed that a group should consist of 6 to 8 people but a greater number is also permitted if time and cost are important factors during the research. In that case, the ongoing monitoring of the quality of interactions taking place between respondents is material so that they do not become dysfunctional. To increase the likelihood of respondents' opinions being accurate, conducting at least a few interviews is recommended. Their
The Practice of Entrepreneurial Competence Development among Students of the Maria Curie-Skłodowska University in Lublin 
IJSR

6

number most frequently ranges from 4 to 8 . The discussion is usually recorded with the use of available audio-visual techniques. A research report containing answers to the research questions asked is compiled on that basis. Authors frequently cite original statements of the respondents in order to reflect the findings more reliably.

In general, we can assume that, in a focused group interview, a moderator leads a discussion based on a predefined scenario with respondents selected according to the criteria resulting from the research objectives (Kitzinger, 1994, pp. 103-121). A benefit of discussion groups is in the dynamics of relations occurring among their members. This factor promotes creativity, facilitates the expression and going beyond the rational dialogue to areas that are not fully conscious or difficult to express (Krueger, 1994; Morgan, 1988). A weakness of the focused group interview is the lack of a representative research sample. The method is used, among other things, to acquire data necessary to define research problems and, after that, to create tools used in the quantitative research conducted on representative samples. After the quantitative research is complete, group discussion also makes it possible to deepen the interpretation of obtained results. In particular, they are worth using in those situations where the statistical representativeness of the research sample is immaterial and, for example, the objective of the exploration is to learn the consumers' reactions to new phenomena, products or ideas (Hague, 2006, pp. 94-108). In the light of the above-mentioned purpose of focused group interviews, it was chosen to be conducted among MCSU students to learn their opinions about:

- the way the essence of entrepreneurship and entrepreneurial attitudes and behaviour are perceived,

- conditions created by the University for entrepreneurial education and for the development of entrepreneurial attitudes and behaviours,

- factors that block entrepreneurship,

- preferred methods of development of entrepreneurial competences.

The research has been conducted among students from 11 MCSU faculties from May to June 2016. The selection of respondents was purposeful regarding the stage of their studies (students of the third year of undergraduate studies and students of the first and second year of postgraduate studies) and random as regards the subjects of exploration. The research was moderated on the basis of the predefined scenario. It contained key problem issues. Each participant in the research could freely present his or her opinions. The research was conducted separately in three student groups consisting of $13-15$ people.

The first group consisted of students of economic faculties such as: finances and accounting, logistics, management and economics. The second group consisted of students of exact sciences studying at the Faculty of Mathematics, Physics and Information Technology, Faculty of Chemistry, Faculty of Biology and Biotechnology, and the Faculty of Earth Sciences and Spatial Management. The third group consisted of students of humanities representing the Art Faculty, Humanities Faculty, Philosophy and Sociology Faculty, Law and Administration Faculty, Political Science Faculty and the Pedagogy and Psychology Faculty. In total, opinions were obtained from 43 respondents. The research duration in one group varied from 60 to 70 minutes. The research was recorded with the use of the audio-visual technology.

Respondents assigned to three groups depending on the profile of studies 
expressed very similar opinions about topics covered in the research. They understood entrepreneurship as creativity, resourcefulness, earning money, multiplying the capital, working freelance, the ability to copy on the labour market, to manage their time, themselves and corporate resources. According to them, an entrepreneurial person should be creative, responsible, courageous, independent, disciplined, aware of the goals, have good interpersonal skills and business-related practical skills. However, it is worth observing that answering questions was most difficult for students in the third group. A great majority of respondents (80\% in group I, $75 \%$ in group II and $90 \%$ in group III) are not interested in managing their own enterprise. Working "for someone else" is more attractive for them as this option makes it possible to gain experience after graduation. Respondents stressed that the lack of business ideas, the fear of failure, the lack of financial funds needed to start and develop their business and the lack of knowledge of how to get them are material problems for them. When asked whether they believed that MCSU students were entrepreneurial, they agreed that entrepreneurial persons can sometimes be found among people known to them but they were few. According to students, their entrepreneurship depends on the direction of studies, with a clear indication of representatives of economic faculties.

The majority of respondents believed that the University insufficiently supports the development of entrepreneurial attitudes and an activity manifesting as the establishment of one's business. According to the respondents, the University offered an opportunity to gain theoretical knowledge of entrepreneurship but too little emphasis was being put on practical classes offering competence necessary to exist on the labour market as an entrepreneur. Offer-related forms of support the respondents mentioned included: training courses, open lectures, projects co-financed from European funds, scientific clubs and student organizations, internships and business incubators. Additionally, the respondents stressed that didactic classes were too theoretical and, for example, the curriculums lack the execution of projects solving actual problems.

All participants in the research expressed positive opinions about the implementation of a project of entrepreneurship education at the University. According to them, the following solutions should be taken into account in it:

- execution of business projects by interdisciplinary teams consisting of representatives of various departments and also graduates,

- organization of study visits to the best firms,

- meetings with business managers,

- focus on courses and workshops rather than lectures,

- obtaining certificates in evidence of the acquisition of certain competencies.

Students would be willing to pay small fees to participate in such a project on the condition that they would have an opportunity to gain experience and valuable competence. Participants in the research considered that the appropriate planning of classes and harmonizing them with the academic calendar would be a material prerequisite of their potential participation in the project. They preferred the weekend mode of studying. One semester is an optimum project execution period from their perspective.
The Practice of Entrepreneurial Competence Development among Students of the Maria Curie-Skłodowska University in Lublin 


\section{IJSR}

6

\section{Table 1.}

Forms of support offered to participants in the Academy of Leaders and the Academy of Business

\section{MCSU Entrepreneurship Academy concept}

The obtained results of literature studies and focus group interviews confirmed that a need exists to develop practical entrepreneurship training and implement at the MCSU. When preparing its concept, the authors decided to take advantage of the positive experience gained during the realization of the project titled "Synergy - modelling of competencies of students at the UMCS Economic Faculty by gaining practical knowledge" in 2009-2014 (Sitko-Lutek, Pastuszak, 2014). A decision was made for the new educational program to be titled "MCSU Entrepreneurship Academy"; its goal will be to train specialists at the Maria Curie-Skłodowska University in Lublin who will be ready to realize their business ideas and to become leaders of commercial and non-profit organizations. It was decided that the Academy will teach competencies related to both the individual and business entrepreneurship. This assumption became the basis for the selection of two education paths: the Academy of Leaders and the Academy of Business. Forms of support offered as a part of both parts are presented in the table below. They are available to University students, graduates and employees.

\begin{tabular}{l|l}
\hline \multicolumn{1}{c|}{ Academy of Leaders } & \multicolumn{1}{c}{ Academy of Business } \\
\hline \multicolumn{2}{l}{ Realization of consulting projects commissioned by enterprises and institutions } \\
\hline Mentoring and networking & \\
\hline Study visits to entrepreneurship pioneers \\
\hline Strategic game & \\
\hline Online competence games & Creating business ideas (University Entrepreneurship Consultation Point) \\
\hline Specialist workshops & Specialist workshops \\
\hline & Acceleration of business ideas (Start-up Weekend) \\
\hline &
\end{tabular}

Source: Internal work.

Participants in both paths will be able to take part in advisory projects commissioned by enterprises and institutions. A group of up to 25 participants will be qualified to the execution of each project and an academic staff member from the University with practical experience in the field of the project will offer the substantive supervision of their work. At least 5 interdisciplinary task teams will be distinguished in each group and each team will prepare one project. The teams will compete, which should contribute to the best quality of results. After the end of the work on projects, they will be presented to Ordering Parties who will evaluate them highlighting strengths and weaknesses of the suggested solutions. Authors of the best project will receive a financial gratification.

The execution of advisory projects is a realization of the "learning by doing" concept.

Additionally, it is an excellent opportunity for the participants to verify theoretical knowledge and learn about the specificity of the consulting work. It can also be an occasion to enrich one's portfolio by adding valuable experience to it and also to get to know the future employer. In turn, benefits for Ordering Parties include: 
- obtaining a few variants of practical solutions of existing problems for free,

- the possibility to obtain valuable human resources with the potential verified in the course of execution of authentic tasks.

In addition to the support of mentors in the course of the execution of advisory projects, cycles of meetings will be organized with business managers: both successful ones and those who experienced a failure. Representatives of institutions obliged to stimulate entrepreneurship will also participate in the meetings. Ultimately, a network of entities and individuals committed to the execution of joint business or social ventures.

Another form of support for participants will consists of study visits to Polish enterprises and institutions occupying leading positions in the area of entrepreneurship thanks to which they can be examples of good practices, sources of inspiration and business ideas. The main motive underlying the organization of study visits is to be able to learn during participating observations.

Members of the Academy of Leaders and the Academy of Business will be able to participate in strategic games. They involve playing a decision-making simulation online. In the course of the game, participants will play the role of managers of industrial enterprises operating in the conditions of fierce competition (an oligopoly with no dominating entity). The objective of the game is to improve the skills and gain experience in the management of a firm. The game offers:

- the efficient execution of the management training related to corporate management in a broad sense that is attractive for participants,

- practical familiarisation of participants with business management principles in competitive conditions,

- integration of knowledge of strategic management, marketing and financial analysis, - learning how to evaluate the condition of an enterprise accurately.

The game stresses the need to prepare an effective business plan for an enterprise and to systematically use results of financial analyses to evaluate the degree of its realization. The game also makes it possible to learn how to compile and interpret the balance sheet, income statement, cash flow statement and several basic financial indicators; therefore, it develops the habit of using financial analysis tools to make decisions in risky conditions and to control the financial liquidity of an enterprise. Having learned the scenario, participants make decisions according to specified deadlines as regards basic areas of the enterprise operations. The curriculum covers 20 decision-making sessions. Prior to the game commencement, it will be necessary to prepare a short version of the business plan (according to the provided template) and the compilation of the final report will be necessary after the end of the game.

Additionally, participants in both Academies will be able to use competence games available online. The player's objective is to find a solution in a problem situation representative for the activity of a manager, employee, vendor or entrepreneur. A participant makes decisions and feels their consequences. The goal is to find an optimum solution in a situation and fulfilling additional requirements of the game that constitute the challenge. Players frequently learn from mistakes they make. However, they have a chance to correct them if they decide to rise up to the challenges again. In this manner, they train their ability to react properly in specific situations, which changes into habits with time.
The Practice of Entrepreneurial Competence Development among Students of the Maria Curie-Skłodowska University in Lublin 
IJSR

6

Competence games make it possible for participants to learn skills in the following areas:

- personal effectiveness,

- team effectiveness,

- management psychology,

- sales.

Academy members will get an unlimited remote access to selected competence games activated in a specific order according to the specially designed program. The program will be created according to the gradualisation rule, which means that a participant is able to play a more advanced game if earlier and, at the same time, easier levels are mastered.

One of the basic barriers hindering the commencement of freelance work is the lack of a business idea. There is a deficit of effective solutions eliminating that issue in the socioeconomic environment. This is why participants of the Academy of Business in particular and also all the other members of the academic community in general will be able to take advantage of the support offered by the University Entrepreneurship Consulting Point as regards:

- the creation of business ideas,

- selection and development of a business model of a venture and its business plan,

- steps to be taken in order to start one's own business,

- formal legal aspects related to the establishment of a firm,

- acquisition of financial funds for the establishment and management of one's business,

- marketing and sales activities in a small firm,

- protection of the intellectual property and commercialization of scientific research results,

- possibilities of support offered by business environment institutions.

Participants in the Academy of Business will take part in a cycle of professional workshops to work on their own business ideas. The workshops will cover the following topics:

1. development of personas for selected customer segments,

2. designing value proposals,

3. business models -25 ways to make profit in business,

4. business strategy development forms,

5. Canvas Business Model,

6. valuation and verification of a new business model before its implementation with the use of the Lean Start-up and Customer Development methods,

7. testing hypotheses with the use of the Experiment Board,

8. introduction to the testing and designing of experiments (Test Card and Learning Card),

9. brand building - how to communicate with first customers (golden circle theory),

10. AARRR analytical method - creating the marketing-sales funnel,

11. generating growth - growth hacking strategy,

12. free online tools useful in the creation of a marketing campaign,

13. transformation sales. 
After the end of the workshop, participants will be able to present their ideas to potential investors during a Start-up Weekend organized by the Lubelski Science \& Technology Park.

The following workshops are planned for participants in the Academy of Leaders:

1. Leadership styles vs. personality types - searching for a natural leadership style training based on the MBTI model;

2. Team building and an effective cooperation in a team - team work training for managers;

3. Emotional intelligence for leaders - emotional intelligence training based on the EQ - and 2.0 model;

4. Building communication for leaders or how to want to work together - NVC training;

5. Accurate decisions. An interdisciplinary expert competence improvement workshop.

\section{Conclusions}

Entrepreneurship training is the obligation of schools of higher education and the realization of their "third mission". As adults, often very experienced, students react positively to such forms of education that are empirical and committing (Twarowski, 2014, p. 48). The MCSU Entrepreneurship Academy offers an opportunity not only to students but also to other members of the academic community to develop their skills related to individual and business entrepreneurship. The developed concept of the MCSU Entrepreneurship Academy is comprehensive and flexible. It is possible to be implemented in any school of higher education in full or in the form of its selected modules depending on the identified needs of the interested parties and financial resources available.

\section{References}

Balan, P., Metcalfe, M. (2012). Identifying Teaching Methods that Engage Entrepreneurship Students. Education and Training, vol. 54, no. 5.

Bandura, A. (1977). Social Learning Theory, General Learning Press, New York.

De Vos, A., Dewilde, T., De Clippeleer, I. (2009). Proactive career behaviors and career success during the early career. Vlerick Leuven Gent Working Paper Series 2009/05.

Galbraith, M.W. (1998). Becoming an Effective Teacher of Adults. In: M.W. Galbraith (ed.), Adult Learning Methods, ( $2^{\text {nd }}$ ed.), Krieger, Malabar.

Gaweł, A. (2014). Gry strategiczne w edukacji przedsiębiorczej. Horyzonty Wychowania, vol. 13, no. 26.

Hague, P. (2006). Badania marketingowe. Planowanie, metodologia i ocena wyników. Wydawnictwo Onepress, Gliwice.

Heinonen, J., Poikkijoki, S.A. (2006). An Entrepreneurial-Directed Approach to Entrepreneurship Education: Mission Impossible? Journal of Management Development, vol. 25, no. 1.

Horyń, W., Maciejewski, J. (eds.), (2007). Andragogika w ujęciu interdyscyplinarnym. Wydawnictwo Uniwersytetu Wrocławskiego, Wrocław.

Izquierdo, E., Deschoolmeester, D. (2010). What Entrepreneurial Competencies should be emphasized in Entrepreneurship and Innovation Education at the Undergraduate Level? 
IJSR

6
In: A. Fayolle (ed.), Handbook of Research on Entrepreneurship Education: International Perspectives. Edward Elgar Publishing, Gheltenham.

Kitzinger, J. (1994). The methodology of Focus Groups: the importance of interaction between research participants. Sociology of Health and Illness, vol. 16, no. 1.

Kolb, A.Y., Kolb, D.A. (2005). The Kolb Learning Style Inventory - Version 3.12005 - Technical Specifications. Hay Resources Direct, Boston.

Kolb, D.A., Boyatzis, R.E., Mainemelis, Ch. (2011). Experiential Learning Theory: Previous Research and New Directions. In: R.J. Sternberg, L. Zhang (eds.), Perspectives on Thinking, Learning and Cognitive Styles. Routledge, New York-London.

Kolb, D.A. (2015). Experiential Learning. Experience as the Source of Learning and Development. Pearson Education, Inc., New Jersey.

Krueger, R.A. (1994). Focus groups: the practical guide goes applied research $\left(2^{\text {nd }}\right.$ ed.), SAGE Publications, Thousand Oaks.

Morgan, D.L. (1988). Focus groups the qualitative research. SAGE Publications, Beverly Hills.

Rabiee, F. (2004). Focus-group interview and data analysis. Proceedings of the Nutrition Society, No. 63.

Recommendation of the European Parliament and of the Council 2006/962/WEof 18 December 2006 on key competences for lifelong learning (OJ UE L 394 of 30.12.2006).

Sitko-Lutek, A., Pastuszak, Z. (eds.), (2014). Synergia nauki i biznesu - interesariusze, kompetencje, innowacje. Wydawnictwo UMCS, Lublin.

Tan, S.S., Ng, C.K.F. (2006). A Problem-Based Learning Approach to Entrepreneurship Education. Education and Training, vol. 48, no. 6.

Tomaszewski, T. (1995). Psychologia ogólna, PWN, Warszawa.

Twarowski, B. (2016). Entrepreneurship determinants among students at the Maria CurieSkłodowska University in Lublin in the light of the conducted research. International Journal of Synergy \& Research, vol. 5.

Twarowski, B. (2014). Synergia - przesłanki, specyfika i efekty realizacji projektu. In: A. SitkoLutek, Z. Pastuszak (eds.), Synergia nauki i biznesu-interesariusze, kompetencje, innowacje. Wydawnictwo UMCS, Lublin.

Wood, R., Bandura, A. (1989). Social Cognitive Theory of Organizational Management. The Academy of Management Review, vol. 14, no. 3.

Wspieranie przedsiębiorczości i innowacji w instytucjach szkolnictwa wyższego w Polsce; OECD and EC report of 2017. 